\title{
DYNAMIC NATURE OF POSTPARTAL CAROTID ARTERY DISSECTION
}

Marjana Vukicevic ${ }^{1}$, Biljana Georgievski Brkic ${ }^{2}$, Tatjana Jaramaz Ducic ${ }^{1}$, Sanja Trajkovic Bezmarevic ${ }^{1}$, Slobodan Culafic ${ }^{3}$

${ }^{1}$ Special Hospital for Cerebrovascular Diseases „Sveti Sava“, Stroke Unit, Belgrade, Serbia

${ }^{2}$ Special Hospital for Cerebrovascular Diseases „Sveti Sava“, Department of Radiology, Belgrade, Serbia

${ }^{3}$ Special Hospital for Cerebrovascular Diseases „Sveti Sava“, Department of Interventional Radiology, Belgrade, Serbia

DINAMIČKA PRIRODA POSTPARTALNE KAROTIDNE DISEKCIJE

Marjana Vukićević ${ }^{1}$, Biljana Georgievski Brkić ${ }^{2}$, Tatjana Jaramaz Dučić1, SanjaTrajković Bezmarevići ${ }^{1}$, Slobodan Ćulafić $^{3}$

${ }^{1}$ Specijalna bolnica za lečenje cerebrovaskularnih bolesti „Sveti Sava“ Moždana jedinica, Beograd, Srbija

${ }^{2}$ Specijalna bolnica za lečenje cerebrovaskularnih bolesti „Sveti Sava“ Odeljenje radiologije, Beograd, Srbija

${ }^{3}$ Specijalna bolnica za lečenje cerebrovaskularnih bolesti „Sveti Sava“ Odeljenje interventne radiologije, Beograd, Srbija

\section{ABSTRACT}

Craniocervical carotid artery dissection (CCAD) is an important cause of stroke in young adults, but it has rarely been reported as a cause of stroke in puerperium.

We report the case of a 27-year-old female with a history of migraine who presented with unilateral left headache, transient episodes of dysphasia and right hemiparesis 30 days after vaginal delivery. The first symptoms started six days after the prolonged childbirth. The first magnetic resonance angiography revealed dissection in the supraclinoid and a cavernous segment of the left Internal carotid artery (ICA). We followed up the patient for two years and she had an unstable course. During this time, she had occlusion of the supraclinoid segment of the left ICA, with caudal extension on the extracranial segment and recanalisation one month later. Two months later, she had intracranial extension with dissection of the left anterior cerebral artery. During this time, she suffered from two strokes with minimal neurological impairment and good clinical recovery.

The pathophysiology of CCAD appears to be multifactorial. Vessel wall injury related to the Valsalva manoeuvre during labour, as well as hemodynamic and hormonal changes of the vessel wall related to pregnancy in a patient with a history of migraine, may be causes of postpartum spontaneous craniocervical artery dissection in healthy women.

Keywords: CCAD, stroke, migraine, pregnancy, postpartum, collateral circulation, MRI, DSA

\section{SAŽETAK}

Kraniocervikalna disekcija karotidne arterije (KDKA) je važan uzrok moždanog udara kod mladih, ali se retko javlja kao uzrok moždanog udara u puerperijumu.

Prikazaćemo slučaj 27 godina stare osobe ženskog pola, koja je hospitalizovana zbog unilateralne glavobolje leve polovine glave, tranzitorne disfazije i desne hemipareze, 30 dana nakon porođaja. Prvi simptomi su nastali šest dana nakon prolongiranog porođaja. Prva angiografija magnetnom rezonancom pokazala je disekciju supraklinoidnog $i$ kavernoznog segmenta leve karotidne arterije. Pacijentkinja je praćena dve godine i imala je nestabilan tok bolesti. Tokom tog vremena imala je okluziju supraklinoidnog segmenta leve karotidne arterije, širenje disekcije u kaudalnom smeru na ekstrakranijalni segment $i$ rekanalizaciju mesec dana kasnije. Nakon dva meseca disekcija se prosirila intrakranijalno na levu prednju moždanu arteriju. Imala je dva moždana udara, minimalno neurološko pogoršanje i dobar klinički ishod.

Patofiziologija KDKA je multifaktorijalna. Povreda zida krvnog suda izazvna Valsalva manevrom tokom porodaja, kao i hemodinamski i hormonski izazvane promene zida u trudnoći, kod pacijenkinja sa migrenom, mogu biti uzrok postpartalne kraniocervikalne karotidne disekcije kod zdravih žena.

Ključne reči: $K D K A$, moždani udar, puerperijum, migrena, kolateralni protok, MR, DSA

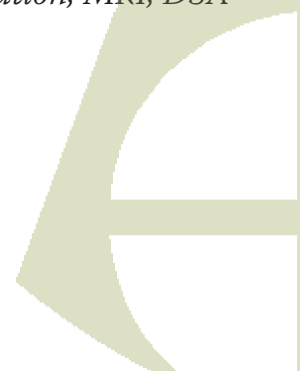

CCAD - craniocervical carotid artery dissection CTA - computed tomography angiography

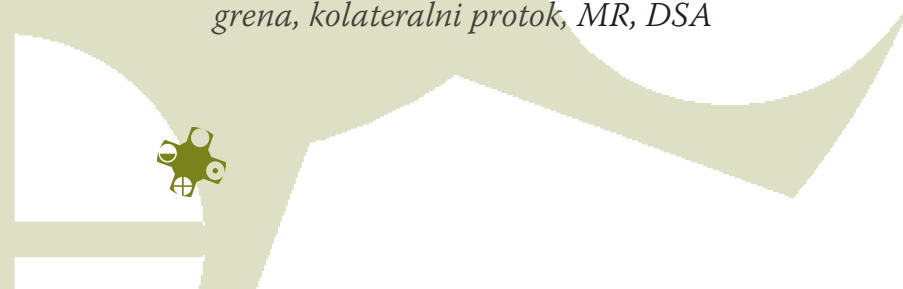

ABBREVIATIONS

DSA - digital selective angiography

ICA - internal carotid artery

MRA - magnetic resonance angiography 


\section{0 \\ ๑

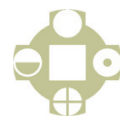

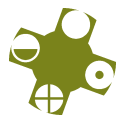

\section{INTRODUCTION}

Pregnancy and the postpartum period are associated with an increased risk of ischemic stroke. The incidence of stroke is 14/100.000 deliveries (1). The relative risk of ischemic stroke during pregnancy is 0.7 but increases to 8.7 during the first four months after childbirth (2). Potential explanations for this increase in reported incidence of stroke include a change in intravascular volume, an effect of hormonal changes during pregnancy on the cerebral arteries, acute lesions of cerebral vessels during delivery, and an abnormality of blood coagulation that increases the risk of arterial thrombosis. An unusual cause of ischemic stroke is extracranial or intracranial artery dissection. Lesions of the arterial vessels supplying the brain due to the dissection are a very rare event in the postpartum period. In women younger than 50 years of age, craniocervical artery dissections (CCAD) occur within 6 weeks after delivery in $6 \%$ of cases (3). We report a case of the CCAD with a complete occlusion of the dissected vessel at the intracranial segment that resulted in an ischemic stroke. At the same time, an extension of intramural hematoma in both the proximal and distal directions was observed. The ischemic stroke was followed by nearly complete recovery. This case report includes a review of the literature on postpartal craniocervical artery dissection.
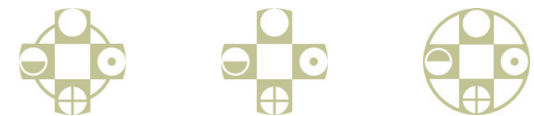

\section{CASE REPORT}

A 27 -year-old female had a family history of migraine and cluster headaches. She had an uneventful pregnancy that was complicated only by labour, which was performed under epidural anaesthesia and lasted for 20 hours. On the sixth day after childbirth, she complained of a severe headache that was localised unilaterally. She also noted occasional clumsiness in her right hand and was anxious that she could drop the baby. To treat her headache, she used common analgesics several times daily. She described her pain as throbbing and located retro-orbitally on the left, and she noted that this headache was different from her usual migraine attacks. After her discharge from hospital, she experienced several headache attacks, but the pain intensity had decreased. She also felt an intermittent weakness in her right hand but thought that this was due to her tiredness. Five weeks after labour, she experienced repeated headaches with increased pain intensity, as well as transient episodes of drowsiness, incomprehensible speech, and weakness in her right hand.

On the admission day, the neurological examination, ECG, blood pressure, and routine blood and biochemical parameters were normal. The carotid duplex ultrasound (MyLab 50, XVision, Esaote, Genoa) showed a reduction in the diffuse vessel diameter in the left internal carotid

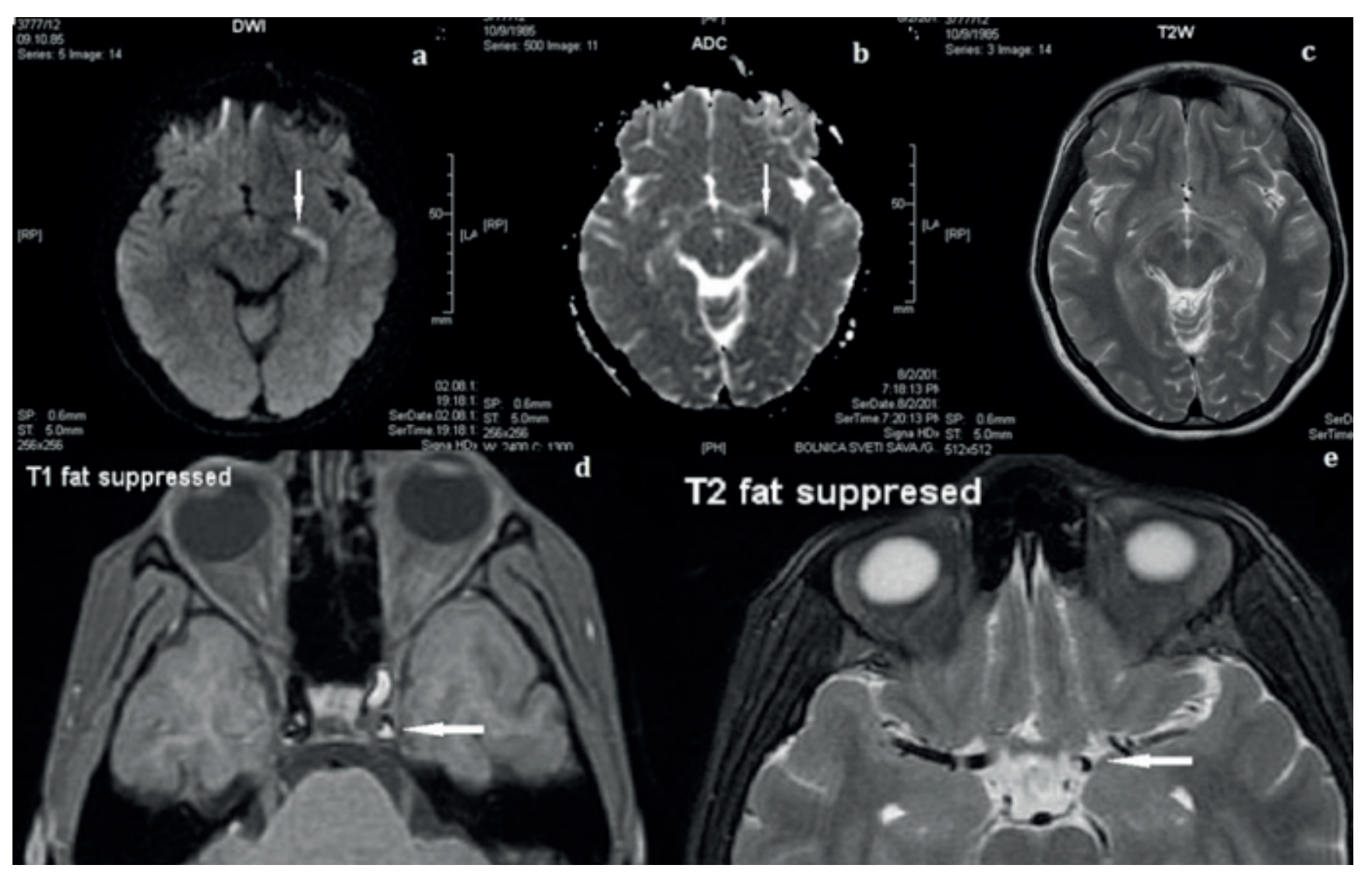

Fig 1. Magnetic resonance images on the admission 

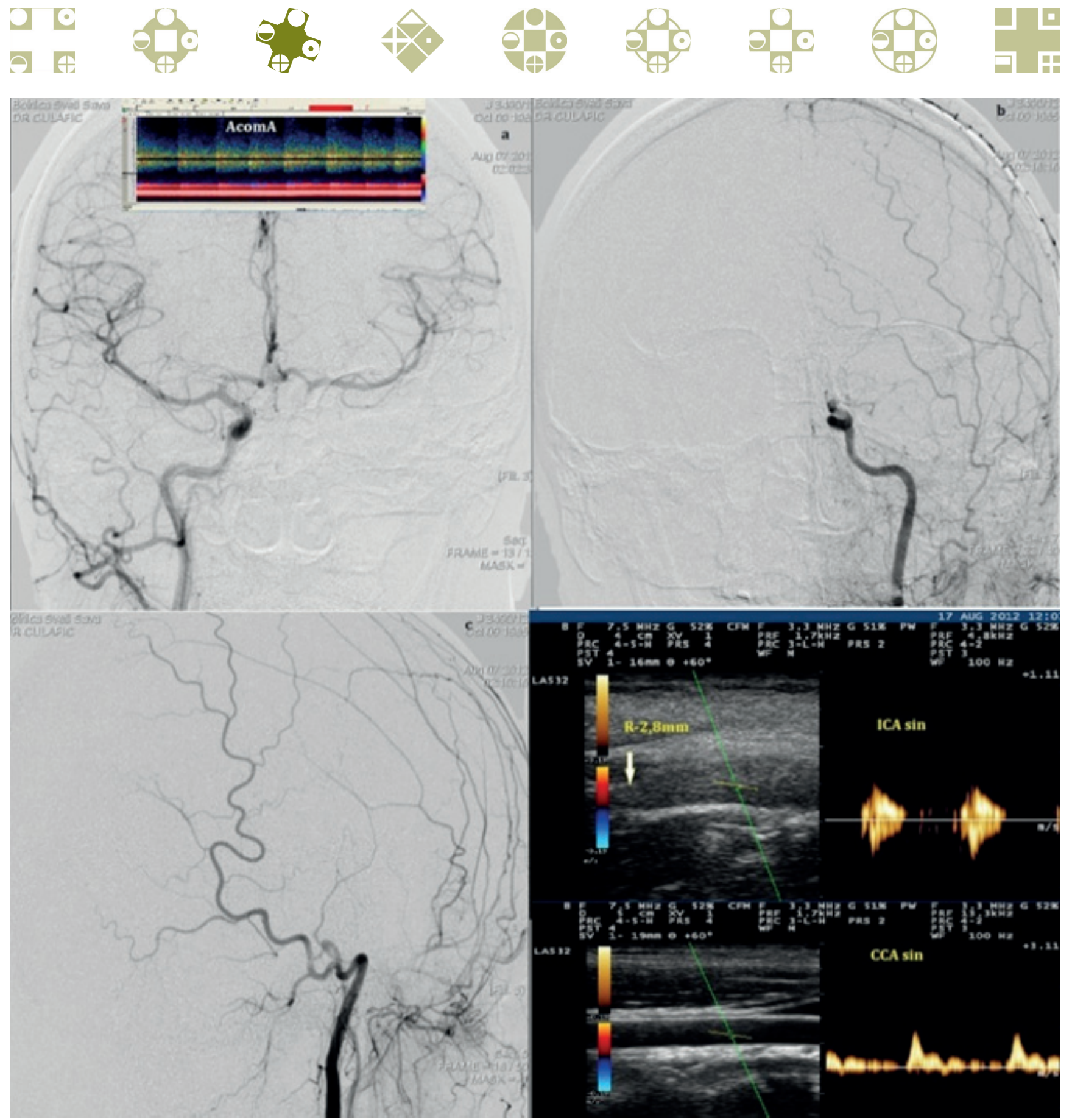

Fig 2. Digital subtractional angiography images with the left approach (a), and the right approach (b, c), color Doppler images of the left common carotid artery and ICA (d).

artery (ICA) compared with the right side. There were no atherosclerotic lesions and disturbances in blood flow velocities. The intima-media thickness (IMT) measured 0,6 $\mathrm{mm}$. The vessel lumen diameters were as follows: right common carotid artery (CCA) - $6.1 \mathrm{~mm}$; left CCA-5.6 mm; right ICA-4.5 mm, left ICA-3.5 mm. The measured peak systolic velocity (PSV) on the right ICA was $140 \mathrm{~cm} / \mathrm{sec}$, and it was $60 \mathrm{~cm} / \mathrm{sec}$ on the left ICA. All magnetic resonance imaging (MRI) examinations were performed on a 1.5-Tesla system (MR Signa, HDx, 1,5T, GE, Milwaukee). MRI with diffusion weighted images (DWI) of the brain showed a hyperacute ischaemic lesion in the left parahippocampal region (Fig. 1a, b, c). Magnetic resonance angi- ography (MRA) with 3D TOF sequences and with axial plane T1 and T2 fat suppressed images presented dissection in the supraclinoid and cavernous segment in the left ICA with a hyperintense T1W intramural hematoma that was asymmetrically surrounded by a narrowed vessel lumen with high-grade stenosis in this segment (Fig. 1e, f). As a variant, an accessory right anterior cerebral artery (ACA) was observed in the A2 segment.

The patient took acetylsalicylic acid $100 \mathrm{mg}$ daily and bromocriptine to stop postpartal milk production. On the sixth day after admission, she had had a series of three transient ischaemic attacks (TIA) lasting up to two minutes that were characterised by aphasia and weakness of 


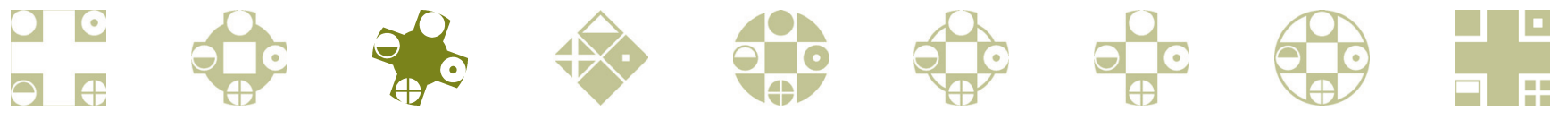

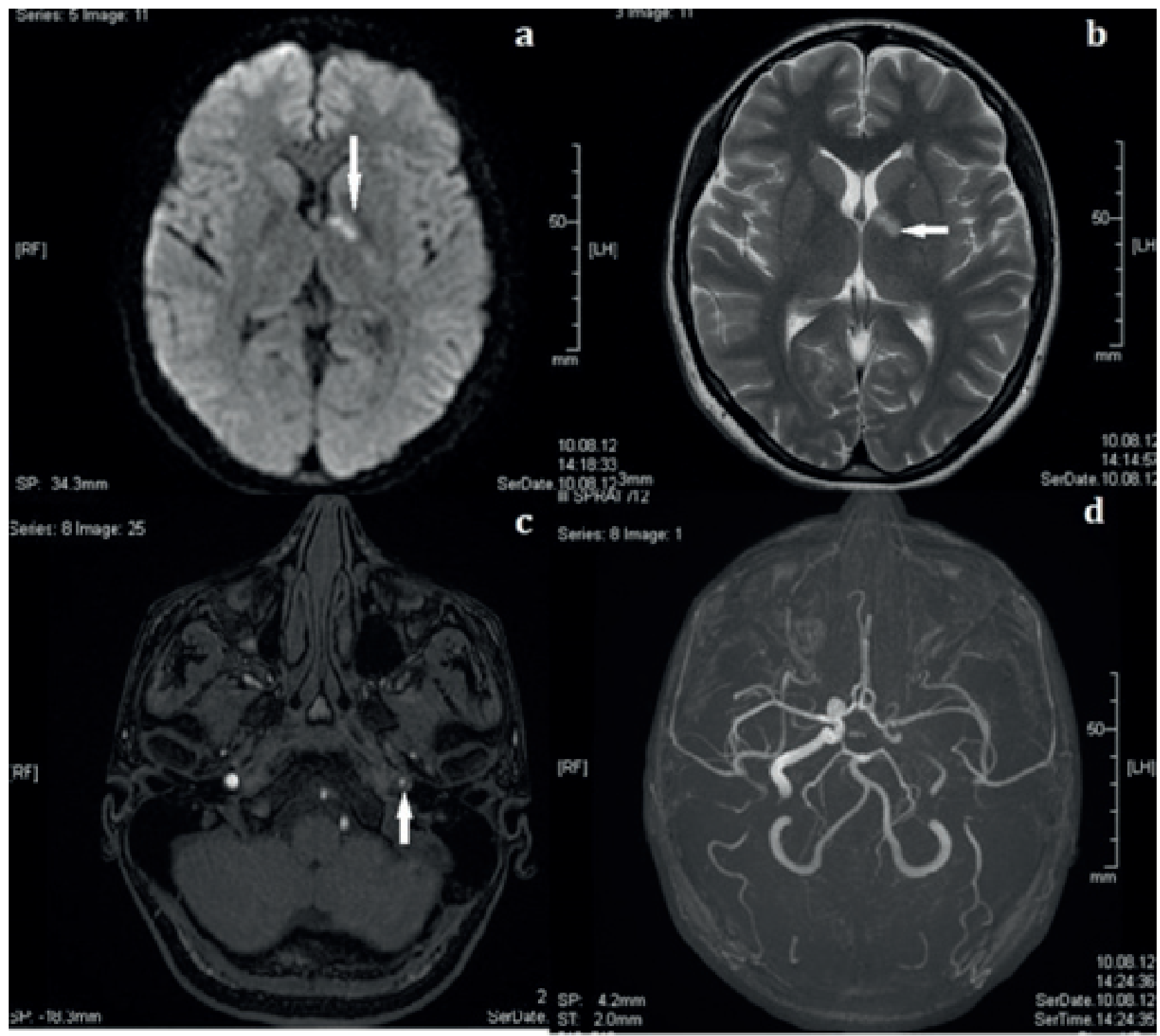

Fig 3. Control magnetic resonance imaging and angiography images four days after DSA

the right side. The fourth TIA was longer and lasted 30 minutes. Digital subtraction angiography (DSA) studies were performed using a digital angiography system (Innova 3100 Single Plane; GE Milwaukee). DSA using the left ICA approach showed an occlusion of the supraclinoid segment of the left ICA, with a visible collateral flow from the external carotid artery (Fig. 2a, c). DSA using an approach from the right ICA revealed good collateral flow through AcomA to the left ACA, middle cerebral artery (MCA), and terminal part of the left ICA over a length of 5 $\mathrm{mm}$ after the origin of ophthalmic artery (Fig. 2b). The carotid duplex showed a high resistance "stump" waveform, with end-diastolic absent flow in the left ICA (Fig. 2d). Four days after DSA, the MRI showed a new acute ischemic lesion in the left basal ganglia (Fig. 3a, b). The MRA showed a slow blood flow in the intracranial petrous segment of the left ICA and an occlusion in the supraclinoid segment, with a distal propagation of arterial wall dissection (Fig. 3c, d).

The patient completely recovered and was dismissed with a modified Rankin score of 0 . After discharge, she took oral anticoagulant (OAC) medication and statin drug. We followed her for two years and monitored the rate of recanalisation by duplex ultrasound and with MRA. One month after occlusion, a duplex scan showed recanalisation with a homogenous smooth surface and thrombosis on the false lumen, with $50 \%$ diameter stenosis. Upon examination thirty days later, recanalisation of the left extracranial segment of ICA was complete, but the transcranial Doppler ultrasound (TCD) showed probable high-grade stenosis of the left terminal-ICA or ACA. The MRI performed 3 months after the onset of disease showed recanalisation with residual $40 \%$ tubular stenosis of the supraclinoid segment of the left ICA over the length of $6 \mathrm{~mm}$. 
Due to an inability to achieve the therapeutic levels of INR, the OAC was terminated, and double antiplatelet therapy was introduced. Another MRI performed 7 months later showed recanalisation in the ACA and residual 20\% stenosis in the supraclinoid segment of the left ICA over a length of $4 \mathrm{~mm}$.

\section{DISCUSSION}

Postpartal CCAD is a rare postpartum complication that accounts for $6 \%$ of spontaneous CCAD in women under 50 years of age, as previously described in case reports and a small number of case studies (3). We reviewed pertinent research articles concerning CCAD within the last fifteen years and found that CCAD occurred within the first six weeks after childbirth (4-15) (Table 1). Dissection is much more common in extracranial segments of the carotid than it is in vertebral arteries. The most preferred site for intracranial carotid artery dissection is the supraclinoid segment beyond the origin of the ophthalmic artery, with or without extension to the MCA or $\mathrm{ACA}(3,16)$. It was observed that CCAD occurred more commonly in older child-bearing females and had a mean age of onset of 33,7 years (5-15) (Table 1). The current view is that CCAD is related to the combination of various intrinsic and extrinsic risk factors. The most important intrinsic factors are generalised arteriopathy that can result in weakness of the arterial wall, vascular anomaly, or genetic predisposition. Extrinsic factors include traumatic lesions of the neck, recent viral infection, and other factors (17) (Table 1). Hormonal changes during pregnancy can result in an increase in intravascular volume and cardiac output and, thus, an impaired arterial distensibility and compliance of large arteries. Karkkainen et al showed that carotid artery elasticity decreased towards the end of pregnancy and was not correlated with either hyperlipidaemia or the diameter of the vessel (18). Furthermore, oestrogens have favourable effects on the vascular endothelium and vascular smooth muscle cells, with an increase in arterial stiffness observed during the postpartal period (19). The CCA tunica media is thinner than the intima layer and has a higher intima/ media ratio during pregnancy. This ratio is dependent on the age, level of oestradiol, blood pressure and BMI of the expecting mother (20). The thinner media can be a predilection site for traumatic lesion. The exceptions are intracranial arteries with very thin tunica adventitia and no external elastic lamina (27).

The association between migraine and CCAD is still unclear. A recent meta-analysis reported that migraine doubles the risk of CAD (22). Tzourio et al. found a highly significant correlation between migraine and serum elastase activity, which is involved in matrix degradation (23). Importantly, postpartal CCAD is associated with a reversible cerebral vasoconstriction syndrome, reversible posterior leukoencephalopathy syndrome, and subarachnoidal haemorrhage without signs of an intracranial extension of CCAD (4). A history of migraine has been frequently reported in patients with reversible cerebral vasoconstriction syndrome during pregnancy and is most likely a result of transient cerebral dysregulation (25). In patients with postpartal CCAD, labour had been performed most commonly via the vaginal route. Only in two cases could the effect of positive intrathoracal pressure (Valsalva manoeuvre) during labour be dismissed because the childbirth was performed by the planned caesarean's section. In the other two cases, the labour was performed by caesarean's section after an unsuccessful vaginal delivery (5-15).

During the Valsalva manoeuvre, the cerebral blood flow velocity can increase up to $50 \%$ (25). This can have an effect on the arterial intima layer. Pain is a main neurological symptom of CCAD and is often very intense at the time of dissection. It is usually located at the retro-orbital, frontal, and/or temporal cranial regions. Unilateral headache and contralateral weakness are the most common neurological symptoms at the onset of disease. Generally, neurological symptoms appear within the first 24 hours but may occur later $(3,24)$. The most common clinical presentations of CCAD are stroke or TIA, and intracranial haemorrhage is less common (4). Haemorrhagic stroke due to an arterial dissection is more common at the intracranial segments of the carotid arteries.

The clinical course of CCAD is unpredictable. There can occasionally be an extension of arterial wall dissection along either the cranial or caudal segments, as observed in our patient. The clinical outcome of cerebral artery dis-

Table 1. The main characteristics of CCAD

\begin{tabular}{|l|l|l|l|l|l|}
\hline $\begin{array}{l}\text { \% of CCAD in } \\
\text { general population }\end{array}$ & $\begin{array}{l}\text { Time of CCAD } \\
\text { occurance }\end{array}$ & $\begin{array}{l}\text { Age of CCAD } \\
\text { occurance (mean) }\end{array}$ & $\begin{array}{l}\text { Enveloped } \\
\text { CCA segment }\end{array}$ & $\begin{array}{l}\text { Factors for } \\
\text { CCAD } \\
\text { development }\end{array}$ & $\begin{array}{l}\text { Clinical } \\
\text { presentation } \\
\text { of CCAD }\end{array}$ \\
\hline Six (6) & $\begin{array}{l}\text { first six weeks } \\
\text { after childbirth }\end{array}$ & 33.7 years & $\begin{array}{l}\text { supraclinoid } \\
\text { segment (beyond } \\
\text { the origin of the } \\
\text { ophthalmic artery) }\end{array}$ & $\begin{array}{l}\text { a) Intrinsic: } \\
\text { generalized } \\
\text { arteriopathy, } \\
\text { vascular } \\
\text { anomaly, genetic } \\
\text { predisposition. b) } \\
\text { Extrinsic: } \\
\text { traumatic lesions } \\
\text { of the neck, } \\
\text { recent viral } \\
\text { infection }\end{array}$ & $\begin{array}{l}\text { 1. stroke, } \\
2 . \text { TIA } \\
\text { hemorrhage } \\
\text { intracranial } \\
\text { recanalization, further } \\
\text { progression of } \\
\text { CAD to the intra } \\
\text { and extracranial } \\
\text { segments }\end{array}$ \\
\hline
\end{tabular}


section may be spontaneous recanalisation. Not rarely, a further progression of CAD to the intra and extracranial segments during first months from onset has been observed (12) (Table 1). The clinical outcome of the arterial dissection is dependent not only on the degree of recanalisation but also on the preserved ability to supply collateral flow through the circle of Willis. Determining these haemodynamic factors during follow-up is necessary via neurosonological or angiographic means. In our patient, the collateral flow was obtained mainly through the AcomA and remained observable even after recovery due to ACA trifurcation. Thus, it is important to access the flow direction in the A1 segment of ACA to avoid the misinterpretation of measurable collateral arterial circulation. The activation of two or more collateral flows is shown to reduce the neurological deficit after stroke due to CCAD and is an important sign for good outcome in these patients (26).

\section{CONCLUSION}

Intense voluntary effort by the mother to deliver the baby during the second stage of labour, along with haemodynamic and hormonal changes of the vessel wall, particularly in patients with a migraine, may cause postpartal CCAD in otherwise healthy women. Postpartal CCAD can have an unpredictable course due to an extension of intramural arterial wall haematoma in either the distal or proximal direction. Good clinical outcome is largely dependent on preserved collateral blood flow. Noninvasive Doppler sonography provides early recognition of CCAD and its subsequent resolution. Regular monitoring of the collateral flow is necessary to access the course of disease and its outcome.

\section{REFERENCES:}

1. Kamel H, Navi BB, Sriram N, Hovsepian DA, Devereux RB, Elkind MSV. Risk of a Thrombotic Event after the 6-Week Postpartum Period. New England Journal of Medicine. 2014;370(14):1307-15.

2. Kittner SJ, Stern BJ, Feeser BR, Hebel JR, Nagey DA, Buchholz DW, et al. Pregnancy and the Risk of Stroke. New England Journal of Medicine. 1996;335(11):768-74.

3. Arnold M, Camus-Jacqmin M, Stapf C, Ducros A, Viswanathan A, Berthet K, et al. Postpartum Cervicocephalic Artery Dissection. Stroke. 2008;39(8):2377-9.

4. Chaves C, Estol C, Esnaola MM, et al. Spontaneous intracranial internal carotid artery dissection: Report of 10 patients. Archives of Neurology. 2002;59(6):977-81.

5. Kelly JC, Safain MG, Roguski M, Edlow AG, MalekAM. Postpartum internal carotid and vertebral arterial dissections. Obstetrics and gynecology. 2014;123(4):848-56.

6. Barroso B, Demasles S. Postpartum four-vessel cervical artery dissection. Cerebrovascular diseases extra. 2013;3(1):150-2.
7. Pires C, Geraldes R, Neto L, Melo TP. Spontaneous multiple cervical artery dissection in the puerperium. Cerebrovascular diseases (Basel, Switzerland). 2011;32(5):511-2.

8. Baffour FI, Kirchoff-Torres KF, Einstein FH, Karakash $S$, Miller TS. Bilateral internal carotid artery dissection in the postpartum period.Obstetrics and gynecology. 2012;119(2 Pt 2):489-92.

9. Abisaab J, Nevadunsky N, Flomenbaum N. Emergency department presentation of bilateral carotid artery dissections in a postpartum patient. Annals of emergency medicine. 2004;44(5):484-9.

10. Soltanolkotabi M, Ansari SA, Shaibani A, Singer TB, Hurley MC. Spontaneous post-partum cervical carotid artery dissection in a patient with reversible cerebral vasoconstriction syndrome. Interventional neuroradiology: journal of peritherapeutic neuroradiology, surgical procedures and related neurosciences. $2011 ; 17(4): 486-9$.

11. Waidelich JM, Bullough AS, Mhyre JM. Internal carotid artery dissection: an unusual cause of postpartum headache. International journal of obstetric anesthesia. 2008;17(1):61-5.

12. Stamboulis E, Raptis G, Andrikopoulou A, Arvaniti C, Brountzos E, Oikonomopoulos N, et al. Spontaneous internal carotid artery dissection: an uncommon cause of recurrent postpartum headache. Journal of neuroimaging: official journal of the American Society of Neuroimaging. 2011;21(1):76-8.

13. Simon EL, Griffin G, Bosman E. Bilateral carotid and vertebral artery dissection: a life-threatening cause of postpartum headache. The American journal of emergency medicine. 2015;33(4):600.e1-3.

14. Hsieh PF, Lee YC, Chang MH. Unilateral carotid and vertebral artery dissections and contralateral subarachnoid hemorrhage in a postpartum patient. Acta neurologica Taiwanica. 2008;17(2):94-8.

15. Oehler J, Lichy C, Gandjour J, Fiebach J, Grau AJ. Dissection of four cerebral arteries after protracted birth. Der Nervenarzt. 2003;74(4):366-9.

16. Nagumo K, Nakamori A, Kojima S. Spontaneous intracranial internal carotid artery dissection: 6 case reports and a review of 39 cases in the literature. Rinshoshinkeigaku -Clinical neurology. 2003;43(6):313-21.

17. Thomas L, Rivett D, Attia J, Levi C. Risk factors and clinical presentation of craniocervical arterial dissection: A prospective study. BMC Musculoskeletal Disorders. 2012;13(1):164.

18. Karkkainen H, Saarelainen H, Valtonen P, Laitinen T, Raitakari OT, Juonala M, et al. Carotid artery elasticity decreases during pregnancy - the Cardiovascular Risk in Young Finns study. BMC pregnancy and childbirth. 2014;14:98.

19. Robb AO, Mills NL, Din JN, Smith IB, Paterson F, Newby $\mathrm{DE}$, et al. Influence of the menstrual cycle, pregnancy, and preeclampsia on arterial stiffness. Hypertension. 2009;53(6):952-8. 
20. Akhter T, Larsson A, Larsson M, Wikstrom AK, Naessen T. Artery wall layer dimensions during normal pregnancy: a longitudinal study using noninvasive high-frequency ultrasound. American journal of physiology Heart and circulatory physiology. 2013;304(2):H229-34.

21. Metso TM, Tatlisumak T, Debette S, Dallongeville J, Engelter ST, Lyrer PA, et al. Migraine in cervical artery dissection and ischemic stroke patients. Neurology. 2012;78(16):1221-8.

22. Rist PM, Diener HC, Kurth T, Schurks M. Migraine, migraine aura, and cervical artery dissection: a systematic review and meta-analysis. Cephalalgia: an international journal of headache. 2011;31(8):886-96.

23. Tzourio C, Benslamia L, Guillon B, Aïdi S, Bertrand $\mathrm{M}$, Berthet $\mathrm{K}$, et al. Migraine and the risk of cervical artery dissection: A case-control study. Neurology. 2002;59(3):435-7.

24. Ducros A. Reversible cerebral vasoconstriction syndrome. The Lancet Neurology. 2012;11(10):906-17.

25. Tiecks FP, Lam AM, Matta BF, Strebel S, Douville C, Newell DW. Effects of the valsalva maneuver on cerebral circulation in healthy adults. A transcranial Doppler Study.Stroke. 1995;26(8):1386-92.

26. Silvestrini M, Altamura C, Cerqua R, Pedone C, Balucani C, Luzzi S, et al. Early Activation of Intracranial Collateral Vessels Influences the Outcome of Spontaneous Internal Carotid Artery Dissection. Stroke. 2011;42(1):139-43.

27. Cipolla MJ. The Cerebral Circulation: Chapter 2, Anatomy and Ultrastructure. San Rafael (CA): Morgan \& Claypool Life Sciences; 2009. 


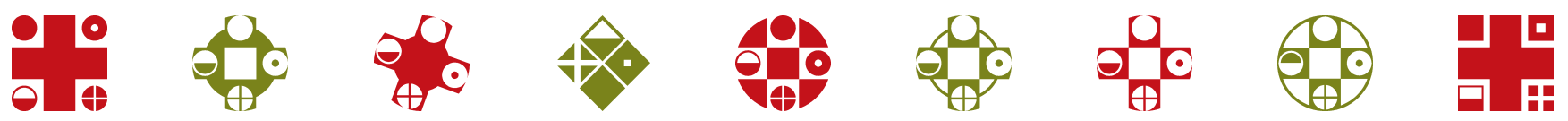

